\title{
Analysis of Nanoprecipitation Effect on Toughness Behavior in Warm Worked AA7050 Alloy
}

\author{
Claudio Testani ${ }^{1, *}\left(\mathbb{D}\right.$, Giuseppe Barbieri $^{2}{ }^{-1}$ and Andrea Di Schino ${ }^{3}(\mathbb{D}$ \\ 1 CALEF, Management Department, c/o ENEA CR Casaccia, Via Anguillarese 301, Santa Maria di Galeria, \\ 00123 Rome, Italy \\ 2 MATPRO Department, ENEA CR Casaccia, Via Anguillarese 301, Santa Maria di Galeria, 00123 Rome, Italy; \\ Giuseppe.barbieri@enea.it \\ 3 Department of Engineering, University of Perugia, Via G. Duranti 93, 06125 Perugia, Italy; \\ andrea.dischino@unipg.it \\ * Correspondence: claudio.testani@consorziocalef.it; Tel.: +39-06-3048-4653
}

Received: 23 November 2020; Accepted: 17 December 2020; Published: 20 December 2020

check for updates

\begin{abstract}
Commonly adopted main methods aimed to improve the strength-toughness combination of high strength aluminum alloys are based on a standard process. Such a process includes alloy solution heat treatment, water-quench and reheating at controlled temperature for ageing holding times. Some alloys request an intermediate cold working hardening step before ageing for an optimum strength result. Recently a warm working step has been proposed and applied. This replaces the cold working after solution treatment and quenching and before the final ageing treatment. Such an alternative process proved to be very effective in improving strength-toughness behavior of 7XXX aluminum alloys. In this paper the precipitation state following this promising process is analyzed and compared to that of the standard route. The results put in evidence the differences in nanoprecipitation densities that are claimed to be responsible for strength and toughness improved properties.
\end{abstract}

Keywords: AA7050 alloy; warm working; toughness

\section{Introduction}

Lightweight metals and alloys represented for many years the most suitable solution for many high-tech applications, including sport equipment [1], energy and automotive [2]. Aerospace has probably been the sector where most of the potential of aluminum and titanium resides. Among lightweight metals, aluminum alloy are gaining huge industrial significance because of their outstanding combination of mechanical, physical and tribological properties [3]. Following such behavior, they appear to be the best candidates for structural aerospace designers if compared with other alloys [4-6]. The origin of their peculiar behavior, depending on different alloying strategies and processes, has been investigated by many researchers in the past years $[7,8]$.

Alloying elements are selected based on their individual properties as they impact on microstructure and performance characteristics. In this framework, the effects of the main alloying elements in aluminum alloys have been reported in detail by Mondolfo in [9]; Sauvage et al. [10] report about the influence of $\mathrm{Cu}$ in hardening behavior of ultrafine-grained Al-Mg-Si alloys.

Among aluminum alloys, AA7050 is one of the best performing taking into account the good balance of high strength, corrosion resistance and toughness, making it largely adopted in aerospace applications [11,12]. Such properties are achieved by recrystallization phenomena during and after hot forming processes [13-16]. Wang et al. recently reported about a physically based constitutive analysis and microstructural evolution investigation in AA7050 aluminum alloy during hot compression [17]. Maizza et al. proposed a recrystallization model for aluminum alloys [18] to be applied to components 
with complex geometric shape, often manufactured by closed-die forging followed by alloy solution heat treatment followed by water-quench and reheating at controlled temperature for ageing holding times. MacKenzie reports in detail about heat treatment effect aluminum forged components [19].

AMS 4333 International Standard prescribes for such alloys an intermediate cold deformation step (max $5 \%$ of cold upsetting) between the water quench, after solution treatment and before the two-stage ageing final step, aimed to reach the optimal precipitate distribution and guarantee the best mechanical properties [20]. One alternative process has been originally proposed by Wyss in the United States Patent US5194102A [21], reporting about the beneficial effect on fracture toughness exerted by an intermediate warm hardening process replacing the cold upsetting step. Such a route has been proved to be successful in 7xxx alloys leading to an improvement in toughness behavior without any detrimental effects in terms of hardness and tensile properties [22]. Moreover, such a process reduces the microstructural heterogeneity by grain refining [23]. As a matter of fact, dislocation cross-slip occurring during deformation in this temperature range allows a general grain reorientation and the sub-boundaries present inside the grains tend to evolve towards high-angle boundaries: the higher the deformation temperature, the easier the process [24]. The process, reported in many papers [25-27], is defined by some authors as continuous dynamic recrystallization (CDR). Other phenomena, such us strain hardening [28,29] and recovery [30], depend on dislocation structure evolution and on its interaction with other crystallographic defects. Cross-slip is recognized as an effective mechanism because it allows dislocations to bypass obstacles and affects the material's final microstructure [31].

In this paper the precipitation state of three different process routes (one standard) are analyzed in correlation with toughness behavior.

\section{Materials and Experimental Details}

The AA7025 alloy nominal chemical composition is reported in Table 1.

Table 1. Nominal chemical composition of the AA7050 alloy (wt \%).

\begin{tabular}{ccccccccccc}
\hline Elements & Al & Zr & Si & Fe & Cu & Mn & Mg & Cr & Zn & Ti \\
\hline wt $(\%)$ & Bal. & 0.12 & $<0.12$ & $<0.15$ & 2.3 & $<0.1$ & 2.2 & $<0.04$ & 6.25 & $<0.05$ \\
\hline
\end{tabular}

Three families of squared $10 \mathrm{~cm} \times 6 \mathrm{~cm} \times 3 \mathrm{~cm}$ samples (namely family A, (samples A1, A2 and A3), family B (samples B1, B2 and B3) and family C (samples C1, C2 and C3)) were machined starting from a round bar, with a starting diameter $D=120 \mathrm{~mm}$. The bar was hot forged at $\mathrm{T}>400{ }^{\circ} \mathrm{C}$ with $75 \%$ total deformation. The heat treatment was adopted in agreement with the requirements from the standard AMS2770N specification since the fulfillment of this standard is mandatory for AA7050 alloy aeronautical forged component manufacturers. The process was completed with room temperature upsetting and final two stages aging at $5 \mathrm{~h}$ at $394 \mathrm{~K}+8 \mathrm{~h}$ at $450 \mathrm{~K}$ (specimens $\mathrm{A}$ ). The two innovative cycles (specimens B and C) just varied from AMS2770N specification requirements in terms of upsetting temperature: in fact, they were carried out at $423 \mathrm{~K}$ and $473 \mathrm{~K}$ instead of room temperature, while all the other cycle steps were unmodified (Table 2). The two temperatures are close and straddling the second ageing step temperature $(T=450 \mathrm{~K})$. Moreover, in the literature [21] it is shown that upsetting temperatures higher than $473 \mathrm{~K}$ can affect hardness values.

Table 2. Modified heat treatment cycles for the AA7050 alloy.

\begin{tabular}{cccccc}
\hline $\begin{array}{c}\text { Sample } \\
\text { Family }\end{array}$ & $\begin{array}{c}\text { Solution Heat } \\
\text { Treatment } \\
\mathbf{T}=\mathbf{7 4 8} \mathbf{K} \text { for } \mathbf{5} \mathbf{h}\end{array}$ & $\begin{array}{c}\text { Water } \\
\text { Quenching }\end{array}$ & $\begin{array}{c}\text { Upsetting Temperature } \\
\text { (Deformation Max 5\%) }\end{array}$ & $\begin{array}{c}\text { First Ageing Step: } \\
\mathbf{3 9 4} \mathbf{K} \text { for } \mathbf{~ h ~}\end{array}$ & $\begin{array}{c}\text { Second } \\
\text { Ageing Step: } \\
\mathbf{4 5 0} \mathbf{~ K} \text { for } \mathbf{~ h ~}\end{array}$ \\
\hline A (1-3) & YES & YES & $293 \mathrm{~K}$ & YES & YES \\
B (1-3) & YES & YES & $423 \mathrm{~K}$ & YES & YES \\
C (1-3) & YES & YES & $473 \mathrm{~K}$ & YES & YES \\
\hline
\end{tabular}


All samples were subjected to solution heat treatment at $\mathrm{T}=748 \mathrm{~K}$ for $5 \mathrm{~h}$, water quenching, $5 \%$ warm deformation and ageing. The process conditions differ on the upsetting temperature, according to Table 2. A1, A2 and A3 specimens were deformed at room temperature; samples B1, $\mathrm{B} 2$ and $\mathrm{B} 3$ at $423 \mathrm{~K}$ and samples; C1, C2 and C3 at $473 \mathrm{~K}$. After heat treatment transverse specimens (in agreement with ASTM-E399) were machined and tested for plain strain fracture toughness (KIC) tests on the transverse specimens (according to the ASTM E399 standard). Samples machined starting from the three families A, B and C were prepared for metallographic examination. Grain size was measured by light microscopy (LM) according to the ASTM E112 specification. Precipitation state analysis was performed with a field emission gun scanning electron microscope (FEG-SEM; SEM FEG LEO 1550 ZEISS equipped with an EDS OXFORD X ACT system, (version v2.2, Oxford Instruments NanoAnalysis \& Asylum Research, Abingdon, UK). Ten micrographs have been examined for each sample in order to establish a statistical base for the quantitative precipitates' analysis. Precipitates number counting has been performed by means of IMAGE-J Fiji, (version 1.46, National Institutes of Health, Bethesda, MD, USA), a software for the automatic images processing and analyses program.

An example of SEM FEG image prepared for precipitation number count by mean of IMAGE-J Fiji 1.46 software is reported in Figure 1.

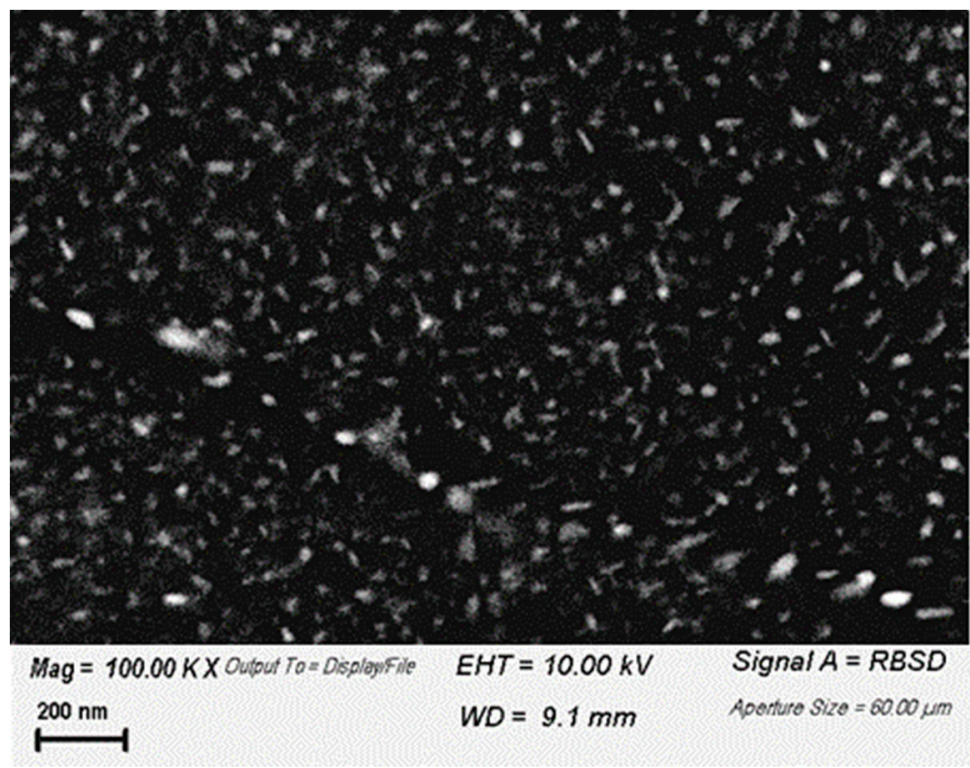

Figure 1. Example of the SEM-FEG high magnification (100 KX) image in sample A.

\section{Results and Discussion}

Microstructural investigation highlighted an actual grain size $\left(D_{g}\right)$ refinement with the increasing upsetting temperature (Figure 2). At the same time, mechanical assessment results (as reported in detail in $[22,23]$ and summarized in Table 3 with the results of averaged grain size) show that, even if hardness and yield strength showed a slight increase, $\mathrm{K}_{\mathrm{IC}}$ performance showed a not negligible improvement. As a matter of fact, the innovative process with upsetting at $\mathrm{T}=473 \mathrm{~K}$ led to an enhancement of about $10 \%$ in fracture toughness $\mathrm{K}_{\mathrm{IC}}$ in comparison to the process cycle carried on in agreement with the AMS2770N specification.

It can be observed that both hardness and tensile mechanical properties increased following the additional upsetting temperature. This suggests that a significant change in fine precipitation occurred, mainly formed from Guiner Preston zones [32,33], acting in terms of grain refinement. Such investigation, aimed to support the mechanism underlying the grain refinement with warm upsetting temperature increase, was not previously carried out, and it is discussed below. 


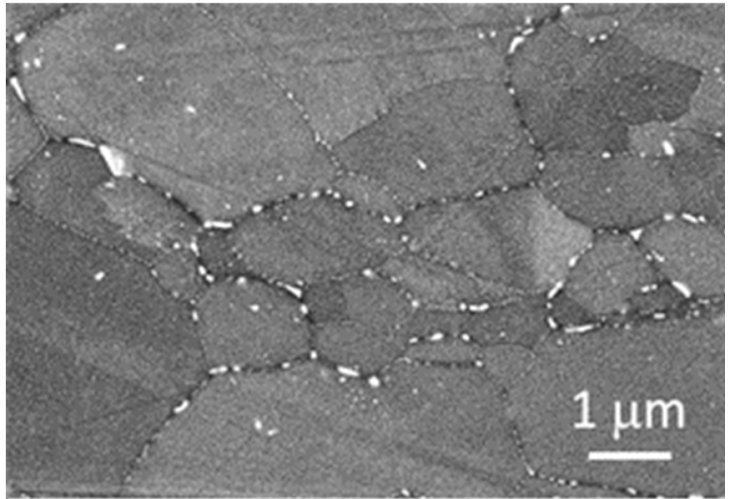

(a)

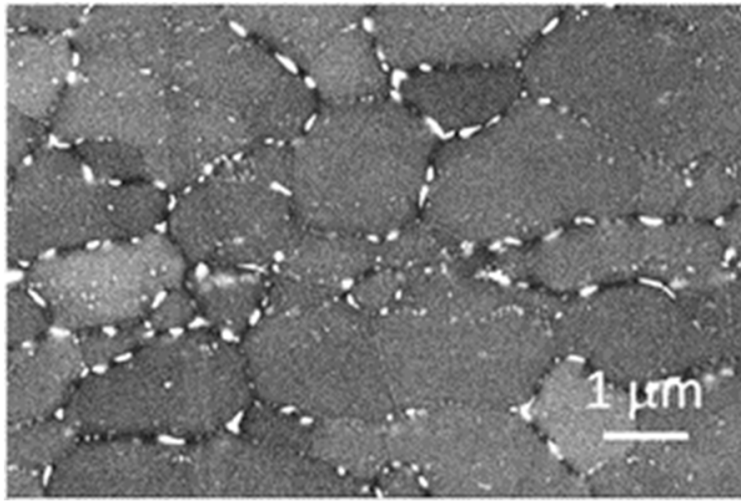

(b)

Figure 2. Warm upsetting temperature effect on the AA7050 alloy microstructure. (a) Warm upsetting temperature $=293 \mathrm{~K}$, average $D_{g}=10.1 \mu \mathrm{m}$ and $(\mathbf{b})$ warm upsetting temperature $=473 \mathrm{~K}$, average $D_{g}=7.5 \mu \mathrm{m}$ (SEM-FEG images at $20 \mathrm{KX}$ magnification).

Table 3. Mechanical properties and mean grain size dependence on warm upsetting temperature in Alloy AA7050.

\begin{tabular}{cccccc}
\hline \multicolumn{1}{c}{ Sample } & $\begin{array}{c}\text { Warm } \\
\text { Upsetting } \\
\text { Temperature }\end{array}$ & $\begin{array}{c}\text { Brinell } \\
\text { Hardness, HB }\end{array}$ & $\begin{array}{c}\text { Yield Strength, } \\
\text { YS (MPa) }\end{array}$ & $\begin{array}{c}\mathbf{K}_{\text {IC }} \\
\text { Mean Value } \\
\text { (MPa m } \mathbf{1 / 2} \text { ) }\end{array}$ & $\begin{array}{c}\text { Average Grain Size } \\
\text { (Dg Microns) }\end{array}$ \\
\hline Sample A (three tests) & $293 \mathrm{~K}$ & 145 & 450 & 26.8 & 10.1 \\
Sample B (three tests) & $423 \mathrm{~K}$ & 147 & 455 & 28.3 & 8.6 \\
Sample C (three tests) & $473 \mathrm{~K}$ & 152 & 470 & 30.1 & 7.5 \\
\hline
\end{tabular}

In order to measure the possible evolution of the overall precipitation status, digital image analysis was performed by setting a Feret diameter threshold of $10 \mathrm{~nm}$. As an example SEM-FEG images of specimens A, B and C are reported in Figure 3.

The scanning electronic microscope SEM-FEG examination of the A, B and C specimens allowed us to have evidence of the following precipitate groups with respect to the size:

- $\quad$ Larger particles at the grain and subgrain boundaries (size ranging $=100-500 \mathrm{~nm}$ );

- $\quad$ Fine particles inside grains subgrains (size ranging $=20-100 \mathrm{~nm}$ );

- Very fine particles inside grains subgrains (size ranging $\leq 20 \mathrm{~nm}$ ).

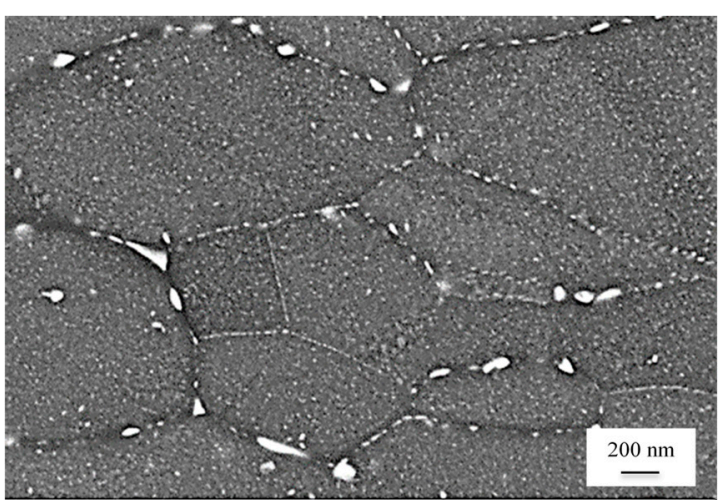

(a)

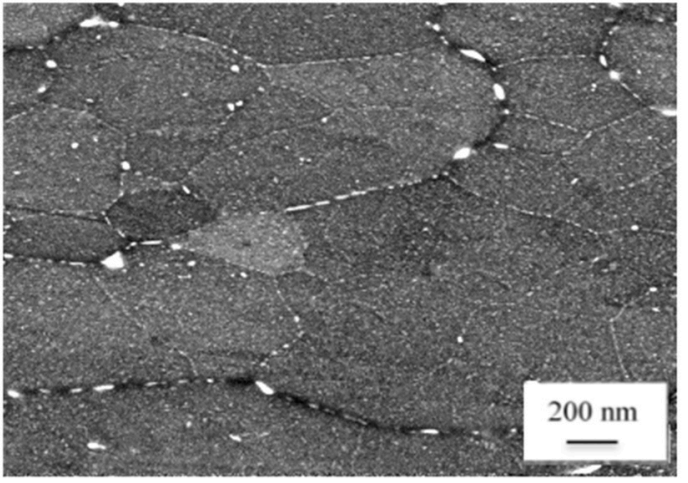

(b)

Figure 3. Cont. 


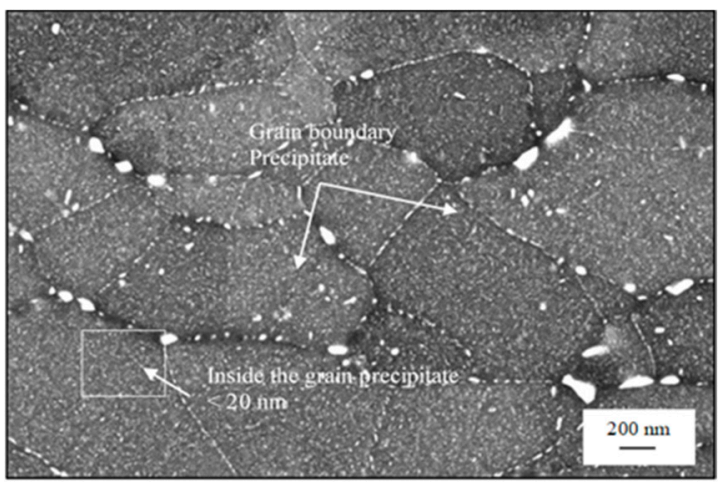

(c)

Figure 3. Warm upsetting temperature effect on the precipitation state of the AA7050 alloy. (a) Specimen A (upsetting at $\mathrm{T}=293 \mathrm{~K}$ ); (b) specimen B (upsetting at $\mathrm{T}=423 \mathrm{~K}$ ) and (c) specimen C (upsetting at $\mathrm{T}=473 \mathrm{~K}$; SEM-FEG images at $50 \mathrm{KX}$ magnification).

In order to carry out an accurate precipitation population assessment, SEM-FEG images at $50 \mathrm{KX}$ and $100 \mathrm{KX}$ were selected. It must be reported that it was possible to detect some larger and isolated particles up to $5 \mu \mathrm{m}$ at grain boundaries, which revealed to be very useful for the chemical analyses [22].

The number of detected precipitates as a function of intermediate upsetting temperature is reported in Figure 4, grouped for different precipitate size ranges.

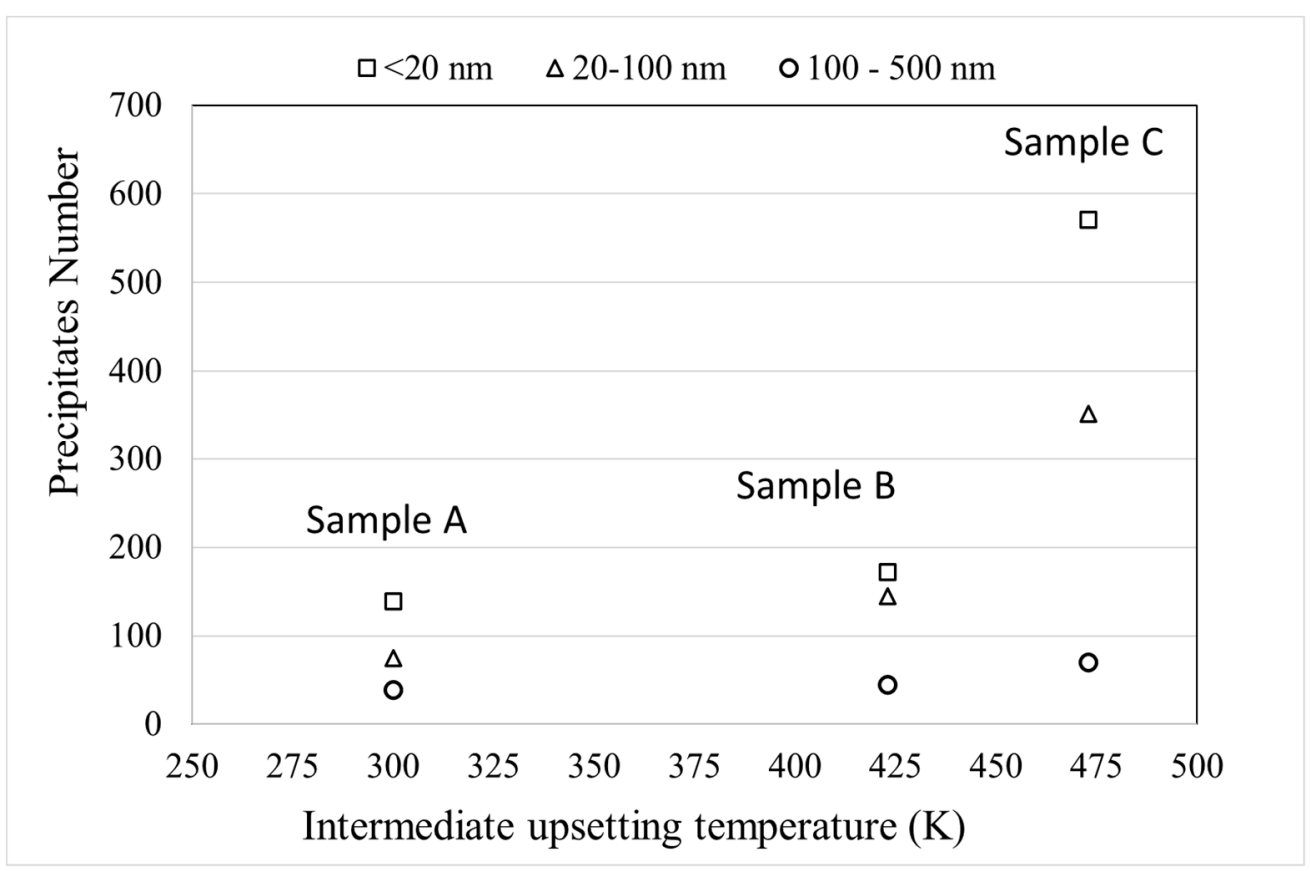

Figure 4. Mean values of precipitates number grouped in size classes (sample A: intermediate upsetting temperature $=293 \mathrm{~K}$; sample B: intermediate upsetting temperature $=423 \mathrm{~K}$; sample C intermediate upsetting temperature $=473 \mathrm{~K})$.

Figure 4 clearly shows that the mean number of precipitates increased, and the intermediate upsetting deformation temperature increased, in the temperature range from 293 to $473 \mathrm{~K}$.

In particular, the mean precipitates number as measured after upsetting at room temperature was very similar to the measured one after warm deformation at $423 \mathrm{~K}$. 
An evident increase of the finest precipitates $(<20 \mathrm{~nm})$ number was found after upsetting at $473 \mathrm{~K}$. Moreover, the increase in upsetting temperature did not appear to affect the largest precipitates. This observation is in agreement with the detected improved toughness and yield strength behavior.

The above results suggest that the appearance of a fine and homogeneous precipitation state will act as a pinning effect at grain boundaries, according to the Zener effect [34]: this will favor a grain refinement down to $7.5 \mu \mathrm{m}$ after upsetting at $473 \mathrm{~K}$, as reported in Table 2 . Such an effect will allow an increase in terms of tensile yield strength together with an improvement in terms of fracture propagation resistance according to the Griffith model [35]. Such a model dictates that the critical stage for cracking is the propagation of a small crack originated in a single grain to the adjacent one and is therefore opposed by grain refinement.

\section{Conclusions}

Results related to the AA 7050 alloy after a modified process route including a warm deformation stage show that:

- The AA7050 alloy precipitation state was very sensitive to heat treatments and especially to the intermediate deformation step included in the heat treatment cycle;

- The warm deformation temperature of $473 \mathrm{~K}$ resulted in the highest nanosized particles precipitation, resulting in increased deformation induced precipitation phenomenon;

- The higher nanosized mean value of precipitations obtained with warm intermediate upsetting steps claimed to be responsible of a grain refinement effect;

- The finer and more homogeneous microstructure resulted in a toughness $\mathrm{K}_{\mathrm{IC}}$ properties improvement with respect to those obtained with room temperature intermediate upsetting step;

- The mechanism underlying the observed behavior was expected to be explained based on the Griffith model for crack propagation, stating that grain boundaries density increased, following a pinning effect. This phenomenon was favored by the presence of fine precipitates and will oppose crack propagation thus improving fracture toughness behavior.

Author Contributions: Conceptualization, C.T. and A.D.S.; Material preparation, A.D.S. and G.B.; SEM-FEG tests; SEM observations G.B. and C.T.; Writing C.T, G.B. and A.D.S. All the authors discussed the results. All authors have read and agreed to the published version of the manuscript.

Funding: This research received no external funding.

Conflicts of Interest: The authors declare no conflict of interest.

\section{References}

1. Napoli, G.; Di Schino, A.; Paura, M.; Vela, T. Colouring titanium alloys by anodic oxidation. Metalurgija 2018, 57,111-113.

2. Sharma, D.K.; Filipponi, M.; Di Schino, A.; Rossi, F.; Castaldi, J. Corrosion behavior of high temperature fuel cells: Issues for materials selection. Metalurgija 2019, 58, 347-351.

3. Warren, A.S. Developments and challenges for aluminium-A Boeing perspective. Mater. Forum 2004, 28, 24-31.

4. Gloria, A.; Montanari, R.; Richetta, M.; Varone, A. Alloys for Aeronautic Applications: State of the Art and Perspectives. Metals 2019, 9, 662. [CrossRef]

5. Aerospace Structural Materials Handbook; DoD, Wright-Patterson Air Force Base: Dayton, OH, USA, 2001.

6. Properties and Selection: Nonferrous Alloys and Special Purpose Materials. In ASM Handbook; American Society of Materials: Cleveland, OH, USA, 2005; Volume 2.

7. Fayomi, O.S.; Popoola, P.; Udoye, N. Effect of Alloying Element on the integrity and Functionality of aluminium-based alloys. In Aluminium Alloys-Recent Trends in Processing, Characterization, Mechanical Behavior and Applications; IntechOpen: London, UK, 2017. [CrossRef]

8. Ranam, R.S.; Purohit, R.; Das, S. Reviews on the Influences of Alloying elements on the Mmcrostructure and Mechanical Properties of Aluminum Alloys and Aluminum Alloy Composites. Int. J. Sci. Res. 2012, 2, 1-7. 
9. Mondolfo, L.F. Aluminum Alloys: Structure and Properties; Butterworth: London, UK, 1976; pp. 497-499.

10. Sauvage, X.; Lee, S.; Matsuda, K.; Horita, M. Origin of the influence of $\mathrm{Cu}$ or Ag micro-additions on the age hardening behavior of ultrafine-grained Al-Mg-Si alloys. J. Alloys Compd. 2017, 710, 199-202. [CrossRef]

11. Sanchez, J.M.; Rubio, E.; Alvarez, M.; Sebastian, M.A.; Marcos, M. Microstructural characterization of material adhered over cutting tool in the dry machining of aerospace aluminium alloys. J. Mater. Process. Technol. 2005, 164-165, 911-918. [CrossRef]

12. Rambabu, P.; Prasad, N.E.; Kutumbarao, V.V.; Wanhill, R.J. Aluminium Alloys for Aerospace Applications. In Aerospace Materials and Material Technologies; Springer: Singapore, 2017; Volume 1, pp. 9-52.

13. Testani, C.; Ielpo, F.M.; Alunni, E. AA2618 and AA7075 alloys superplastic transition in isothermal hot-deformation tests. Mater. Des. 2001, 21, 305-310. [CrossRef]

14. Zhao, Y.H.; Liao, X.Z.; Hin, Z.; Valiev, R.Z. Microstructures and mechanical properties of ultrafine grained $7075 \mathrm{Al}$ alloy processed by ECAP and their evolutions during annealing. Acta Mater. 2004, 52, 4589-4599. [CrossRef]

15. Rufini, R.; Di Pietro, O.; Di Schino, A. Predictive Simulation of Plastic Processing of Welded Stainless Steel Pipes. Metals 2018, 8, 519. [CrossRef]

16. Di Schino, A.; Di Nunzio, P.E.; Turconi, G.L. Microstructure evolution during tempering of martensite in medium carbon steel. Mater. Sci. Forum 2007, 558-559, 1435-1441. [CrossRef]

17. Wang, S.; Luo, J.; Hou, L.; Zhang, J.; Zhuang, L. Physically based constitutive analysis and microstructural evolution of AA7050 aluminum alloy during hot compression. Mater. Des. 2016, 107, 277-289. [CrossRef]

18. Maizza, G.; Pero, R.; Richetta, M.; Montanari, R. Continuous dynamic recrystallization (CDRX) model for aluminum alloys. J. Mater. Sci. 2017, 53, 4563-4573. [CrossRef]

19. MacKenzie, D. Scott Heat Treating Aluminum for Aerospace Applications. Heat Treat. Prog. 2005, 5, $37-43$.

20. Aluminum Alloy, Die Forgings, 6.2Zn-2.3Cu-2.2Mg-0.12Zr (7050-T7452), Solution Heat Treated, Compression Stress-Relieved, and Overaged; AMS 4333 International Standard; SAE International: Warrendale, PA, USA, 2015.

21. Wyss, R. ALCOA, Method for Increasing the Strength of Aluminum Alloy Products through Warm Working. U.S. Patent 5,194,102, 16 March 1993.

22. Angella, G.; Di Schino, A.; Donnini, R.; Richetta, M.; Testani, C.; Varone, A. AA70323 Al alloy hot-forging process for improved fracture toughness properties. Metals 2019, 9, 64. [CrossRef]

23. Tedde, M.; Di Schino, A.; Donnini, R.; Montanari, R.; Richetta, M.; Santo, L.; Testani, C.; Varone, A. An innovative industrial process for forging 70323 Al alloy. Mater. Sci. Forum 2018, 941, 1047-1052. [CrossRef]

24. Gourdet, S.; Montheillet, F. Effects of dynamic grain boundary migration during the hot compression of high stacking fault energy metals. Acta Mater. 2002, 50, 2801-2812. [CrossRef]

25. McQueen, H.J. Development of dynamic recrystallization theory. Mater. Sci. Eng. A 2004, 387-389, $203-208$. [CrossRef]

26. Humphreys, F.J.; Hatherly, M. Recrystallization and Related Annealing Phenomena, 2nd ed.; Elsevier: Amsterdam, The Netherlands, 2004.

27. Di Schino, A.; Di Nunzio, P.E. Metallurgical aspects related to contact fatigue phenomena in steels for back up rolling. Acta Metall. Slovaca 2017, 23, 62-71. [CrossRef]

28. Jackson, P.J. The role of cross-slip in the plastic deformation of crystals. Mater. Sci. Eng. 1983, 57, 39-47. [CrossRef]

29. Saada, G. Cross-slip and work hardening of fcc crystals. Mater. Sci. Eng. A 1991, 137, 177-183. [CrossRef]

30. Poirier, J.P. On the symmetrical role of cross-slip of screw dislocations and climb of edge dislocations as recovery process controlling high-temperature creep. Rev. Phys. Appl. 1976, 11, 731. [CrossRef]

31. Hussein, A.M.; Rao, S.I.; Uchic, M.D.; Dimiduk, D.M.; El-Awady, J.A. Microstructurally based cross-slip mechanisms and their effects on dislocation microstructure evolution in fcc crystals. Acta Mater. 2015, 85, 180-190. [CrossRef]

32. Jarzebska, A.; Bogucki, R.; Bieda, M. Influence of degree of deformation and aging time on mechanical properties and microstructure of aluminium alloy with zinc. Arch. Metal. Mat. 2015, 60, 215-221.

33. De Hass, M.; De Hosson, T.H. Grain Boundary segregation and precipitation in aluminium alloys. Scripta Mat. 2001, 44, 281-286. [CrossRef]

34. Nes, E.; Ryum, M.; Huneri, O. On the Zener drag. Acta Metal. 1985, 33, 11-22. [CrossRef] 
35. Astarita, A.; Testani, C.; Scherillo, F.; Squillace, A.; Carrino, L. Beta Forging of a Ti6Al4V Component for Aeronautic Applications: Microstructure Evolution. Metall. Microstruct. Analy. 2014, 3, 460-467. [CrossRef]

Publisher's Note: MDPI stays neutral with regard to jurisdictional claims in published maps and institutional affiliations.

(C) 2020 by the authors. Licensee MDPI, Basel, Switzerland. This article is an open access article distributed under the terms and conditions of the Creative Commons Attribution (CC BY) license (http://creativecommons.org/licenses/by/4.0/). 